New insights into carnitine-acylcarnitine translocase deficiency from twenty-three cases:

management challenges and potential therapeutic approaches.

Ryder $\mathbf{B}^{1,2}$, Inbar-Feigenberg $\mathbf{M}^{1}$, Glamuzina $E^{2}$, Halligan $\mathbf{R}^{3,4}$, Vara $\mathbf{R}^{4}$, Elliot $A^{5}$,

Coman $D^{5,14}$, Minto $T^{5}$, Lewis $K^{5}$, Schiff $\mathbf{M}^{6,7}$, Vijay $S^{3}$, Akroyd $\mathbf{R}^{2}$, Thompson $\mathrm{S}^{8,9}$,

MacDonald A ${ }^{3}$, Woodward AJM ${ }^{10}$, Gribben JEL ${ }^{10}$, Grunewald S ${ }^{11}$, Belaramani ${ }^{12}$,

Hall $\mathrm{M}^{13}$, van der Haak $\mathrm{N}^{13}$, Devanapalli $\mathrm{B}^{8}$, Tolun $\mathrm{AA}^{8}$, Wilson $\mathrm{C}^{2}$, Bhattacharya $\mathrm{K}^{8,9}$

${ }^{1}$ Division of Clinical and Metabolic Genetics, The Hospital for Sick Children, Toronto,

Ontario, Canada

${ }^{2}$ National Metabolic Service, Starship Children’s Hospital, Auckland, New Zealand

${ }^{3}$ Department of Inherited Metabolic Disorders, Birmingham Women's and Children's Hospital Foundation Trust, Steelhouse Lane, Birmingham, UK.

${ }^{4}$ Department of Metabolic Medicine, Evelina Children’s Hospital, London UK.

${ }^{5}$ Queensland Lifespan Metabolic Medicine Service, Queensland Children’s Hospital, Brisbane, QLD, Australia

${ }^{6}$ Reference Centre for Inherited Metabolic Diseases, AP-HP, Necker University Hospital,

University of Paris, France

${ }^{7}$ INSERM U1163, Institut imagine, Paris, France

${ }^{8}$ Department of Metabolic Genetics, Sydney Children’s Hospitals’ Network NSW, Australia

${ }^{9}$ Faculty of Health and Medical Science, University of Sydney, NSW, Australia

${ }^{10}$ Department of Nutrition \& Dietetics, Evelina London Children’s Hospital

${ }^{11}$ Metabolic Medicine Department, Great Ormond Street Hospital, Institute of Child Health

University College London, NIHR Biomedical Research Centre, London, UK.

${ }^{12}$ Department of Metabolic Medicine, Hong Kong Children’s Hospital, Hong Kong

${ }^{13}$ Departments of Metabolic Medicine \& Nutrition, Women's and Children's Hospital, North Adelaide, SA

This article has been accepted for publication and undergone full peer review but has not been through the copyediting, typesetting, pagination and proofreading process which may lead to differences between this version and the Version of Record. Please cite this article as doi: 
${ }^{14}$ School of Medicine University of Queensland and Griffith University, Brisbane, Queensland Australia.

\section{Corresponding author}

Bryony Ryder ` National Metabolic Service, Starship Children’s Hospital, Auckland, New Zealand.

bryonyr@adhb.govt.nz

Author Guarantor - Dr Kaustuv Bhattacharya

Word count article 2973

Word count Summary 242

Figures - 3 tables; 1 figure

- Supplementary material: Appendix 1

44 references 


\section{$\underline{\text { Summary }}$}

\section{Background}

Carnitine acyl-carnitine translocase deficiency (CACTD) is a rare autosomal recessive disorder of mitochondrial long-chain fatty-acid transport. Most patients present in the first two days of life, with hypoketotic hypoglycaemia, hyperammonaemia, cardiomyopathy or arrhythmia, hepatomegaly and elevated liver enzymes.

\section{Method}

Multi-centre international retrospective chart review of clinical presentation, biochemistry, treatment modalities including diet, subsequent complications, and mode of death of all patients.

\section{Results}

Twenty-three patients from nine tertiary metabolic units were identified. Seven attenuated patients of Pakistani heritage, 6 of these homozygous c.82G>T, had later onset manifestations and long-term survival without chronic hyperammonemia. Of the sixteen classical cases, fifteen had cardiac involvement at presentation comprising cardiac arrhythmias (9/15), cardiac arrest (7/15) and cardiac hypertrophy (9/15). Where recorded, ammonia levels were elevated in all but one severe case (13/14 measured) and 14/16 had hypoglycaemia. Nine classical patients survived longer-term - most with feeding difficulties and cognitive delay. Hyperammonaemia appears refractory to ammonia scavenger treatment and carglumic acid, but responds well to high glucose delivery during acute metabolic crises. High-energy intake seems necessary to prevent decompensation. Anaplerosis utilizing therapeutic D,L-3hydroxybutyrate, Triheptanoin and increased protein intake, appeared to improve chronic hyperammonemia and metabolic stability where trialled in individual cases. 


\section{Conclusion}

CACTD is a rare disorder of fatty acid oxidation with a preponderance to severe cardiac dysfunction. Long-term survival is possible in classical early-onset cases with long-chain fat restriction, judicious use of glucose infusions, and medium chain triglyceride supplementation. Adjunctive therapies supporting anaplerosis may improve longer-term outcomes.

Short title - Treatment of CACTD

Synopsis CACTD is typically a rare severe fat oxidation disorder presenting with hyperammonaemia, hypoglycaemia and cardiac dysfunction, which can sometimes be treated with high glucose delivery and anaplerotic agents.

\section{Contributions of Authors}

Ryder B Study design, data collection, analyses, writing all drafts

Inbar-Feigenberg $\mathbf{M}$ Study design, analyses, strategic direction

Glamuzina E Study design, analyses, strategic direction

Halligan R Contribution of data to cases

Vara R Contribution of data to cases

Elliot A Diet data provided for cases

Coman D Contribution of data to cases

Minto T Contribution of data to cases

Lewis K Contribution of data to cases

Schiff M Contribution of data to cases

Vijay S Contribution of data to cases

Akroyd R Diet data provided for cases 
Thompson S Diet data provided for cases

MacDonald A Diet data provided for cases

Woodward AJM Diet data provided for cases

Gribben JEL Diet data provided for cases

Grunewald S Contribution of data to cases

Belaramani K Contribution of data to cases

Hall M Contribution of data to case

Van der Haak Diet data provided for cases

Devanapalli B Contribution to laboratory methodology

Tolun AA Contribution to laboratory methodology and construction of figure 2

Wilson C Study design, analyses, strategic direction

Bhattacharya K Study design, data collection, analyses, writing all drafts, creation of graphs and figures. Guarantor

Competing Interests - Dr Inbar-Feigenberg received compassionate access to medication (Triheptanoin) from Ultragenyx for one patient. All other authors declare no conflict of interest.

Funding - This study was not funded.

Ethical statement - Over arching ethics was performed at The Hospital for Sick Children, Toronto, Canada. Patients were consented to provide case report data per local practices.

\section{Key words}

Carnitine acyl-carnitine translocase deficiency, carnitine shuttle, hyperammonaemia, ketones, Triheptanoin, anaplerosis 


\section{INTRODUCTION}

Carnitine-acylcarnitine translocase deficiency (CACTD) (OMIM\#212138) is a rare autosomal recessive disorder of fatty acid oxidation (FAO) ${ }^{1}$. The incidence in Caucasian populations is estimated at 1:750,000-1:2,000,000 increasing to 1:60,000 in Hong Kong ${ }^{2}$. CACT is a component of the carnitine shuttle, essential for import of long chain fatty acids into the mitochondria matrix for beta-oxidation ${ }^{3}$. CACTD results in an inability to produce energy from long chain fatty acid metabolism and a proposed deficiency of free Coenzyme A (CoA) for essential reactions such as the tricarboxylic acid (TCA) cycle and oxidation of pyruvate. Symptoms of CACTD are purported to arise from the deficiency of acetyl CoA, and the toxic effects of accumulating long-chain acylcarnitine moieties ${ }^{4,5}$.

Clinically CACTD resembles the other severe long chain FAO disorders. Patients most commonly present in the first two days of life with hypoketotic hypoglycaemia, cardiomyopathy or arrhythmias, hepatomegaly with raised liver transaminases and elevated creatine kinase (CK). Hyperammonemia is a prominent feature and may lead to suspicion of a urea cycle disorder or organic acidemia. CACTD has the highest rate of cardiac arrhythmia and mortality amongst fatty acid oxidation disorders. ${ }^{2}$

An acylcarnitine profile showing elevations most pronounced in C16, C18 and C18:1 acylcarnitine species suggests either CACT or CPTII deficiency (OMIM\#608836). These disorders are indistinguishable on acylcarnitine profile therefore diagnosis is confirmed by 
enzyme activity level or molecular analysis ${ }^{6}$. Urine organic acids may show a dicarboxylic aciduria (DCA) ${ }^{5}$.

Treatment of CACTD like other severe long-chain FAO disorder’s, consists generally of a diet normal in energy and protein, high in carbohydrate, low in long-chain triglycerides (LCT), and supplemented with ketogenic medium chain triglycerides (MCT) $)^{5,7,8}$. Lipolysis is inhibited by avoidance of fasting and the use of high carbohydrate fluids during illness ${ }^{3,9}$. Accumulation of toxic long-chain acylcarnitines is limited by restriction of dietary long-chain fat to less than $10 \%$ of total caloric intake ${ }^{1,8,10,11}$. Carnitine is generally administered, doses ranging from $50-300 \mathrm{mg} / \mathrm{kg} /$ day ${ }^{1,4,8}$.

Only 68 cases of CACTD have been reported in the literature. This report aims to further characterize this rare disease by describing the clinical, biochemical, molecular findings and treatment of 23 patients with CACTD.

\section{METHOD}

The study was approved by the Institutional Research Ethics Board of The Hospital for Sick Children, Toronto. Local consent processes were followed for review and publication of deidentified patient data. There were no exclusion criteria. This is a retrospective review of 23 cases of CACTD from metabolic centres in New Zealand, Australia, Canada, UK and Hong Kong (four previously reported). All patients with available data and a diagnosis of CACTD confirmed by CACT enzyme activity and/or molecular analysis were included in the study.

\section{RESULTS}

Individual case reports are available for all cases as online appendix 1. 


\section{Classical}

16/23 cases had severe classical disease (Table 1) defined as a catastrophic collapse within 48 hours of birth (10-48 hrs). One was deemed classical despite presenting on day eight of life, being homozygous for variant c.199-10T>G which is associated with a severe phenotype in six patients in this cohort and other publications ${ }^{2,10}$. One was treated pre-symptomatically. Only 1 classical untreated case did not manifest hypoglycaemia.

Severe neonatal cardiac dysfunction was demonstrated in 2/16 at presentation, one with fractional shortening 11-16\% (normal 28 - 45\%) and another requiring inotrope support post cardiac arrest, until care was withdrawn. 4/16 had normal echocardiograms, 10/16 had arrhythmias at presentation, predominantly supraventricular and ventricular tachycardia, seven of these presenting with cardiac arrest requiring cardiopulmonary resuscitation (CPR) (Table 1). Of those with a normal echo at presentation all but one remained normal at follow up. Of eleven classical patients who survived beyond one year, , there was generally a trend for improvement: five had normal function, four had borderline to moderate LVH without cardiac dysfunction. One developed dilated cardiomyopathy at 3 years of age, and one had hypertrophic cardiomyopathy.

Hyperammonaemia was noted in 14/16 classical patients at presentation (range 50-1142 umol/, including one patient treated pre-symptomatically) and was not measured in the remaining two. All but one had chronic recurrent hyperammonemia despite intensive therapy. The patient that had no chronic hyperammonaemia (patient 10) took more total energy and protein than the other cases and used D,L-3-hydroxybutyrate during intercurrent illness (table 2). Seven patients had no sustained improvement on ammonia scavenging medications. Carglumic acid was 
trialled in two without clear benefit. All responded well in the acute setting to high rates of dextrose administration (10-12 $\mathrm{mg} / \mathrm{kg} / \mathrm{min})$. One patient had improvement in hyperammonemia after starting D,L-3-hydroxybutyrate and Triheptanoin (C7) soon thereafter.

Creatine Kinase levels were raised in 13/14 measured, up to >25,000 U/L 9/16 had evidence of acute renal injury at presentation, reflected in raised urea or creatinine. One had renal Fanconi syndrome in the neonatal period and two developed proximal renal tubular acidosis later in life. 3/16 developed unexplained chronic, severe diarrhoea improving with metronidazole in one patient. All surviving classical patients had liver echogenicity consistent with steatohepatitis or hepatomegaly. Two developed gallstones at 2 and 4 years of age and one had liver fibrosis at 10 years. No patients developed pancreatitis.

6/16 were deceased, two in the first week and the remainder aged 6 months- 4 years. The surviving 10 classical patients range in age from 5 months to 11 years with normal neurocognitive outcome reported in $4 / 9$ over one year of age. Formal neurocognitive assessments were only available in two patients.

\section{Attenuated}

7/23 cases were attenuated (Table 3), with confirmed homozygosity for variant c.82G> T (p.Gly28Cys), hereafter referred to as "attenuated variant", in 6/7. These patients were all of Pakistani descent. 3/7 were treated pre-symptomatically. 4/7 presented clinically, between 9 days and 4 months of age.

Five had no evidence of cardiomyopathy on echocardiogram at presentation and remained normal at follow up, one had mild left ventricular hyper trabeculation and one presented at two months of age with asystolic arrest requiring CPR and echocardiogram findings of LVH 
and impaired contractility. Longer term this patient had persistent hypertrophic cardiomyopathy. Only 1/7 attenuated case had hyperammonaemia at presentation and none had chronic hyperammonaemia.

All 7 attenuated patients are living. Five are felt to have normal neurocognitive function, without formal neurocognitive assessment, and two require some learning support in mainstream schooling.

\section{DISCUSSION}

Prior to this cohort of twenty-three patients just 68 CACTD cases have been reported, with few patients surviving into their second decade. Four patients in this cohort have been reported before ${ }^{12-14}$. The majority of cases present prior to a NBS result, often with ventricular arrhythmia and cardiorespiratory arrest. NBS may therefore expedite the diagnosis but does not generally allow pre-symptomatic treatment in classical cases.

Hyperammonaemia is both a presenting feature and chronic long-term management issue in classical CACTD ${ }^{1,5,15-17}$, occurring in more than $50 \%{ }^{11}$. The hyperammonaemia is not well understood and there are sparse real time data during acute decompensation. Secondary hyperammonaemia may occur due to inhibition of ureagenesis by either toxic metabolites or substrate deficiency. Quantifiable urea cycle intermediates were not identified in the original report of CACTD ${ }^{1}$, hence it was proposed that hyperammonaemia occurred due to insufficiency in the proximal part of the urea cycle. One of our cases had quantifiable orotate possibly indicating deficiency distal to carbamoyl-phosphate. Stanley et al concluded that 
insufficient acetyl Co-A for synthesis of $\mathrm{N}$-acetylglutamate was unlikely to be the cause of hyperammonaemia, given its persistence despite MCT supplementation. Consistent with this, is the inadequate response to carglumic acid reported in the literature and observed in our cohort $(n=1)$. An improvement in hyperammonaemia was noted during a course of metronidazole for treatment of Clostridium difficile in two patients, leading to regular cycling of monthly metronidazole in patient 7 . The presumptive mechanism would be clearance of bacteria which produce propionyl-CoA in the gut however a lack of response to carglumic acid would argue against the possibility of propionyl CoA inhibiting NAGS (OMIM \#237310). The nitrogen efflux from mitochondria into the cytosol, to be incorporated into urea, is dependant on either glutamate or aspartate ${ }^{18,19}$. Glutamate dehydrogenase oxidation of glutamate to 2-ketoglutarate and ammonia is favoured when cellular energy is low, GDH being activated to maintain energy generation through the oxidation of amino acids ${ }^{18}$. Of note, high mitochondrial GTP, ATP or palmitoyl-CoA concentrations would inhibit this process ${ }^{18}$. Aspartate efflux from the mitochondrion is also dependant on the TCA intermediate oxaloacetate ${ }^{19}$. Hence, in the setting of acute energy deficit, the provision of anaplerotic agents is likely to enhance ammonia incorporation into urea (Figure 1). It has been proposed that energy deficit may be part of the reason for hyperammonaemia in organic acidaemias although short chain fatty acid inhibition of NAGS also occurs ${ }^{20}$. ATP-dependent cytosolic glutamine synthase (E.C. 6.3.1.2) is another major route of ammonia detoxification, producing glutamine from glutamate and ammonia ${ }^{21}$. The provision of glutamate or its precursors, is thought to stimulate GS, thereby enhancing ammonia removal by increased synthesis of glutamine. Hyperammonaemia in CACTD is not associated with elevated glutamine, perhaps due to GS downregulation at times of severe energy deficit. 
Aside from the response to glucose, hyperammonaemia in this cohort of patients appears to have responded to sodium D,L-3-hydroxybutyrate and an increase in dietary protein, which would provide anaplerosis ${ }^{13,22}$. Triheptanoin is proposed to provide superior anaplerosis because heptanoyl CoA is metabolised to both acetyl- and propionyl-CoA as well as 4 and 5 carbon ketone bodies. The provision of both even and odd chain carbon intermediates to the TCA cycle is proposed to result in improved balance of the TCA cycle however the evidence for its use in CACTD remains limited. The safety and long-term efficacy of triheptanoin has been described in three infants with severe cardiogenic shock unresponsive to standard treatment ${ }^{22,23}$. Within our cohort one patient was felt to be clinically more stable on triheptanoin, but this was introduced shortly after sodium D,L-3-hydroxybutyrate and liver enzymes, CK and ammonia levels, and cardiac function had normalised prior to the introduction of triheptanoin. Patient 1 developed raised CK levels after starting triheptanoin at 34 months of age therefore triheptanoin was stopped. He then developed dilated cardiomyopathy, dying of cardiac failure at 42 months of age.

Chronic hyperammonaemia was a prominent feature in 9 classical patients surviving infancy. High rates (10-12 mg/kg/min) of IV dextrose was the most effective acute management and a minimum dietary carbohydrate intake seemed necessary to prevent chronic recurrent hyperammonaemia ${ }^{8,24}$. While a high dietary carbohydrate intake is effective, the cost longer term was excessive weight gain, hepatomegaly and steatohepatitis. The metabolic consequences of impaired long-chain fatty acid transport into the mitochondria, is enhanced de novo cytosolic lipogenesis ${ }^{25}$. This leads to hepatic steatosis that is further exacerbated if chronically excessive carbohydrate or medium chain triglyceride is given ${ }^{26,27} .10 / 14$ severe patients surviving infancy had evidence of steatohepatitis, 2/14 with gallstones and 1/14 
developed liver fibrosis by 10 years of age. The hyperammonaemia in this patient (Case 8) appeared less responsive to acute carbohydrate administration, possibly related to the reduction in GS expression in patients with liver cirrhosis ${ }^{23}$. This has led to consideration of therapeutic liver transplant.

Ammonia scavenging medications such as sodium benzoate and sodium phenylbutyrate have a limited effect ${ }^{28}$. When started concurrently with dextrose it is difficult to attribute effect, as hyperammonaemia generally responds promptly to high rates of intravenous glucose independent of medication use. ${ }^{16}$ Within this cohort there was an inadequate response to ammonia scavengers and no response to protein restriction. In fact, perhaps via induction of urea cycle enzymes or by anaplerotic effect, greater metabolic stability (cases 10 and 12) and improved hyperammonemia (cases 8,10,12 and 16) was observed with higher protein intake $(2-4 \mathrm{~g} / \mathrm{kg} /$ day $)$ with a reduction in number of hospital admissions ${ }^{29}$. Furthermore, complications related to steatosis are less likely with higher protein intake compared to high MCT or carbohydrate intake ${ }^{30}$.

This cohort highlights renal involvement in CACTD. Steatosis of the renal tubules, particularly proximal tubules, is found on post mortem ${ }^{7,31-34}$. All forms of renal involvement, as observed in this cohort, have been previously reported; renal tubulopathy, hyperkalaemia and oliguric renal failure with acute tubular necrosis ${ }^{11,32,35}$.

Reported GI disturbance consists of feeding difficulties, gastrostomy tube dependence, gastroesophageal reflux, impaired motility, recurrent vomiting and diarrhoea ${ }^{1,4,16,36}$. Within this cohort, feeding difficulties and vomiting were frequently observed. Unexplained severe chronic diarrhoea was noted in three, with improvement in diarrhoea and hyperammonemia 
in one patient who received metronidazole. Prescribed feeding regimes with excessive oligosaccharides and MCT oil may contribute to osmotic diarrhoea and modify gut flora longer term. Pancreatitis has been observed in a case of CACTD (personal communication), but was not seen in our cohort.

CACTD is characterised by a high-esterified fraction of acylcarnitines ( $>90 \%$, normal $<30 \%)$ and extremely low free carnitine levels, often as low as 1-2 mmol/l ${ }^{1}$. It has been proposed that high dose carnitine may worsen the accumulation of potentially cardiotoxic long-chain acylcarnitines ${ }^{37}$. Cumulative experience in CACTD at L-carnitine doses ranging from 50$300 \mathrm{mg} / \mathrm{kg} /$ day suggests supplementation does not lead to cardiotoxicity ${ }^{5,8,16,36}$. Esterification with carnitine may be the only route of detoxification of toxic acyl-CoA intermediates ${ }^{8}$. It is possible that the acylcarnitines accumulating in CACTD may be less toxic outside the mitochondrial matrix ${ }^{7}$. Within this cohort, patients received up to $200 \mathrm{mg} / \mathrm{kg} / \mathrm{day}$ L-carnitine but generally did not achieve normal free carnitine levels. Accumulating acylcarnitines may inhibit reabsorption of free carnitine by the carnitine transporter, resulting in renal carnitine wastage ${ }^{1}$.

The majority of reported patients receive q3-4 hourly diurnal feeds and continuous overnight feeds, to limit fasting and provide adequate calories. Clinical deterioration has been noted with fasting intervals greater than four hours in neonates with a severe presentation ${ }^{38}$. The fasting limitations recommended for severe patients within this cohort ranged from three hours to eight hours. Clinical deterioration was observed in two classical patients when fasting intervals were extended to twelve and eight hours, with improvement when fasting duration was reduced. Based on these findings, extended fasts would not be recommended in classical CACTD but the optimal fasting duration at different ages has not been defined. 
CACTD patients have been demonstrated to generate ketones on administration of MCT formula with only partial utilization of C10 MCT ${ }^{39,40}$. Treatment with MCT formula aims to bypass the translocase defect however fatty acyl moieties of C10 length or longer account for 20-50\% of total fatty acids in most commercially available MCT formulae and C10 fatty acids are also dependent on the carnitine shuttle. Approximately 40\% of administered MCT could be inadequately oxidized in patients, so a formula containing less C10 and C12 MCT would therefore seem preferable. Some centres prefer a fat free formula with replenishment of MCT. Under-utilisation of C10 accounts for excessive energy requirement in CACTD. Generation of beta-hydroxybutyrate in CACTD on MCT loading can be less than $50 \%$ of that in VLCADD (MIM\#201475) ${ }^{8}$. The exogenous ketone sodium D,L-3-hydroxybutyrate was given in 7 severe cases (patients 7-10, 12,13,16), as an assured source of ketones, with variable effect. Doses ranged from 300-900mg/kg/day. Patient 10 presented with a profound neonatal cardiac dysfunction, which appeared to respond dramatically to exogenous ketones, similar to that described in multiple acyl-CoA dehydrogenase deficiency ${ }^{41-43}$. Patient 9 had improved metabolic stability after starting ketones and Triheptanoin (C7) at a similar time point, therefore it was difficult to know which intervention led to clinical improvement.

There is significant genetic heterogeneity in SLC25A20, and phenotype-genotype correlations are limited by numerous private mutations. The c.199-10T $>$ G splice site variant is the most common mutation identified ${ }^{44}$. This variant appears to be the reason for the increased incidence of CACTD in the Chinese population. The variant is associated with a severe presentation, frequently with cardiac arrest, within the first 3 days of life ${ }^{2,45}$. 2/5 homozygous patients in this cohort died suddenly and unexpectedly of cardiac causes at 6 months and 3 years of age, while the other 3/5 homozygous are living, aged 5 months- 4 years. One patient 
heterozygous for this variant is alive with borderline LVH. Variant p.Gly28Cys, c.82G>T was identified in six patients in this cohort, and appears to be associated with Pakistani ethnicity and an attenuated phenotype ${ }^{11,31}$; although was more severe in 2 compound heterozygotes in this cohort.

This retrospective case review faced several constraints. Data was incomplete for some cases; treatment, particularly dietetic management, naturally changed over time in response to the patient's clinical condition and some interventions were made concurrently. This prevented definitive conclusions being made regarding treatment effect. Trends for improvement are instead noted and the need for further research and improved collaborative registry based data collection highlighted.

\section{Conclusion}

This large cohort offers valuable insight into long-term management challenges experienced in CACTD, and potential therapeutic modalities requiring further investigation. Most patients have a severe classical course with onset of symptoms within the first 48 hours, and cases diagnosed through newborn screening remain rare. Despite early recognition and treatment, outcomes remain poor with high rates of sudden cardiac death and progressive neurocognitive disability in classical cases, potentially due to initial catastrophic presentation and recurrent hyperammonemia. The preponderance and pathogenesis of severe acute cardiac compromise and hyperammonemia in CACTD, relative to other FAODs, remains unexplained. The attenuated variant c. $82 \mathrm{G}>\mathrm{T}$ may still cause significant illness but there is later onset and the potential for better longer term outcome due to the absence of chronic hyperammonemia. 
Patients with CACTD seem to respond well to treatment with high rates of glucose infusion during acute decompensation. Early detection and standard treatment with high rates of IV dextrose and MCT feeds, may allow survival of the initial insult but long-term survival outcomes are sub-optimal using current treatment strategies. C10 MCT is probably underutilised leading to acetyl Co-A deficiency. Acute energy deficit may result in sudden, frequently cardiac death, which may occur in the context of prolonged fasting. For survivors within this cohort, there has been a trend for improvement with greater energy delivery from other sources (higher protein intake, D,L-3-hydroxybutyrate and Triheptanoin) but further research is required to define the role of these agents.

\section{Acknowledgments}

The authors would like to thank Dr Drago Bratkovic and Dr David Ketteridge for their contributions to the cases. They would also like to acknowledge Dr Jim McGill and Professor Bridget Wilcken for proofreading the manuscript and Marjorie Dixon and A. Lewis from Great Ormond Street Hospital for their contributions. The authors would like to acknowledge the various intensive care unit staff, paediatricians and specialists that contribute to the care of these patients. The authors thank all the families for contributing to this research.

\section{Legends for Figures}

\section{Figure 1. Acute and chronic complications of CACTD}

Number of cases with presenting features of classical (left bar) and attenuated (right bar) DD. Chronic complications in survivors over one year of age. 
(1)

e

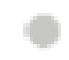

1

Q

1

$+1$

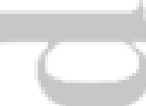

(1)

$+$

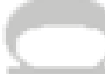

(1)

(

( )

4 


\section{$\underline{\text { References }}$}

1. Stanley CA, Hale DE, Berry GT, Deleeuw S, Boxer J, Bonnefont JP. Brief report: a deficiency of carnitine-acylcarnitine translocase in the inner mitochondrial membrane. N Engl J Med 1992; 327(1): 19-23. doi: 10.1056/NEJM199207023270104.

2. Yan $\mathrm{HM}, \mathrm{Hu} H$, Ahmed A, et al. Carnitine-acylcarnitine translocase deficiency with c.199-10 T>G and novel c.1A>G mutation: Two case reports and brief literature review. Medicine (Baltimore) 2017; 96(45): e8549. doi: 10.1097/MD.0000000000008549.

3. Longo N, Amat di San Filippo C, Pasquali M. Disorders of carnitine transport and the carnitine cycle. Am J Med Genet C Semin Med Genet 2006; 142C(2): 77-85. doi: 10.1002/ajmg.c.30087.

4. Roschinger W, Muntau AC, Duran M, et al. Carnitine-acylcarnitine translocase deficiency: metabolic consequences of an impaired mitochondrial carnitine cycle. Clin Chim Acta 2000; 298(1-2): 55-68. doi: 10.1016/s0009-8981(00)00268-0.

5. Rubio-Gozalbo ME, Bakker JA, Waterham HR, Wanders RJ. Carnitine-acylcarnitine translocase deficiency, clinical, biochemical and genetic aspects. Molecular aspects of medicine 2004; 25(5-6): 521-32.

6. Saudubray JM, Martin D, de Lonlay P, et al. Recognition and management of fatty acid oxidation defects: a series of 107 patients. J Inherit Metab Dis 1999; 22(4): 488-502. doi: 10.1023/a:1005556207210.

7. Chalmers RA, Stanley CA, English N, Wigglesworth JS. Mitochondrial carnitineacylcarnitine translocase deficiency presenting as sudden neonatal death. J Pediatr 1997; 131(2): 220-5. doi: 10.1016/s0022-3476(97)70157-4.

8. Parini R, Invernizzi F, Menni F, et al. Medium-chain triglyceride loading test in carnitine-acylcarnitine translocase deficiency: insights on treatment. J Inherit Metab Dis 1999; 22(6): 733-9. doi: 10.1023/a:1005548201355.

9. Arnold GL, Van Hove J, Freedenberg D, et al. A Delphi clinical practice protocol for the management of very long chain acyl-CoA dehydrogenase deficiency. Molecular genetics and metabolism 2009; 96(3): 85-90.

10. Hsu BY, lacobazzi V, Wang Z, et al. Aberrant mRNA splicing associated with coding region mutations in children with carnitine-acylcarnitine translocase deficiency. Mol Genet Metab 2001; 74(1-2): 248-55. doi: 10.1006/mgme.2001.3235.

11. Vitoria I, Martin-Hernandez E, Pena-Quintana L, et al. Carnitine-acylcarnitine translocase deficiency: experience with four cases in Spain and review of the literature. JIMD reports 2015; 20: 11-20.

12. Pierre G, Macdonald A, Gray G, Hendriksz C, Preece MA, Chakrapani A. Prospective treatment in carnitine-acylcarnitine translocase deficiency. J Inherit Metab Dis 2007; 30(5): 815. doi: 10.1007/s10545-007-0518-x. Epub 2007 May 12.

13. Bhattacharya K, Matar W, Tolun A, et al. The use of Sodium DL-3-Hydroxybutyrate in severe acute neuro-metabolic compromise in patients with inherited ketone body synthetic disorders. Orphanet Journal of Rare Disease 2019.

14. Hammond J, Sim KG, Trenholm A, Stanley EL, Wilcken B. Sudden Infant Death in Infancy - Two NZ cases of Carnitine acylcarnitine translocase deficiency. Journal of inherited metabolic disease 1998; 21(Suppl 2): 60. 
15. Lopriore E, Gemke RJ, Verhoeven NM, et al. Carnitine-acylcarnitine translocase deficiency: phenotype, residual enzyme activity and outcome. Eur J Pediatr 2001; 160(2): 101-4. doi: 10.1007/s004310000644.

16. Costa C, Costa JM, Nuoffer JM, et al. Identification of the molecular defect in a severe case of carnitine-acylcarnitine carrier deficiency. J Inherit Metab Dis 1999; 22(3): 267-70. doi: 10.1023/a:1005590223680.

17. Costa C, Costa JM, Slama A, et al. Mutational spectrum and DNA-based prenatal diagnosis in carnitine-acylcarnitine translocase deficiency. Mol Genet Metab 2003; 78(1): 6873. doi: 10.1016/s96-7192(02)00205-6.

18. Stanley CA. Hyperinsulinism/hyperammonemia syndrome: insights into the regulatory role of glutamate dehydrogenase in ammonia metabolism. Mol Genet Metab 2004; 81(Suppl 1): S45-51. doi: 10.1016/j.ymgme.2003.10.013.

19. Saheki T, Kobayashi K, lijima M, et al. Adult-onset type II citrullinemia and idiopathic neonatal hepatitis caused by citrin deficiency: involvement of the aspartate glutamate carrier for urea synthesis and maintenance of the urea cycle. Mol Genet Metab 2004; 81(Suppl 1): S20-6. doi: 10.1016/j.ymgme.2004.01.006.

20. Haberle J, Chakrapani A, Ah Mew N, Longo N. Hyperammonaemia in classic organic acidaemias: a review of the literature and two case histories. Orphanet J Rare Dis 2018; 13(1): 219. doi: 10.1186/s13023-018-0963-7.

21. Soria LR, Nitzahn M, De Angelis A, et al. Hepatic glutamine synthetase augmentation enhances ammonia detoxification. J Inherit Metab Dis 2019; 42(6): 1128-35. doi: 10.002/jimd.12070. Epub 2019 Mar 11.

22 Mahapatra S, Ananth A, Baugh N, Damian M, Enns GM. Triheptanoin: A Rescue Therapy for Cardiogenic Shock in Carnitine-acylcarnitine Translocase Deficiency. JIMD reports 2018; 39:19-23.(doi): 10.1007/8904_2017_36. Epub Jul 9.

23. Vockley J, Charrow H, Ganesh J et al. Triheptanoin Treatment in Patients with Pediatric Cardiomyopathy Associated with Long Chain-Fatty Acid Oxidation Disorders. Mol Genet Metab 2016; 119 (3) 223-231. doi: 10.1016/j.ymgme.2016.08.008

24. lacobazzi V, Invernizzi F, Baratta S, et al. Molecular and functional analysis of SLC25A20 mutations causing carnitine-acylcarnitine translocase deficiency. Hum Mutat 2004; 24(4): 312-20. doi: 10.1002/humu.20085.

25. Giudetti AM, Stanca E, Siculella L, Gnoni GV, Damiano F. Nutritional and Hormonal Regulation of Citrate and Carnitine/Acylcarnitine Transporters: Two Mitochondrial Carriers Involved in Fatty Acid Metabolism. International journal of molecular sciences 2016; 17(6).

26. Prentki M, Corkey BE, Madiraju SRM. Lipid-associated metabolic signalling networks in pancreatic beta cell function. Diabetologia 2019; 19(10): 019-04976.

27. Tucci S, Flogel U, Hermann S, Sturm M, Schafers M, Spiekerkoetter U. Development and pathomechanisms of cardiomyopathy in very long-chain acyl-CoA dehydrogenase deficient (VLCAD(-/-)) mice. Biochimica et biophysica acta 2014; 1842(5): 677-85.

28. Pande SV, Brivet M, Slama A, Demaugre F, Aufrant C, Saudubray JM. Carnitineacylcarnitine translocase deficiency with severe hypoglycemia and auriculo ventricular block. Translocase assay in permeabilized fibroblasts. J Clin Invest 1993; 91(3): 1247-52. doi: $10.172 / \mathrm{JCl} 116288$.

29. Gillingham MB, Elizondo $G$, Behrend $A$, et al. Higher dietary protein intake preserves lean body mass, lowers liver lipid deposition, and maintains metabolic control in participants with long-chain fatty acid oxidation disorders. J Inherit Metab Dis 2019; 42(5): 857-69. doi: 10.1002/jimd.12155. Epub 2019 Jul 24. 
30. Tucci S, Herebian D, Sturm M, Seibt A, Spiekerkoetter U. Tissue-specific strategies of the very-long chain acyl-CoA dehydrogenase-deficient (VLCAD-/-) mouse to compensate a defective fatty acid beta-oxidation. PloS one 2012; 7(9): e45429.

31. Morris AA, Olpin SE, Brivet M, Turnbull DM, Jones RA, Leonard JV. A patient with carnitine-acylcarnitine translocase deficiency with a mild phenotype. J Pediatr 1998; 132(3 Pt 1): 514-6. doi: 10.1016/s0022-3476(98)70030-7.

32. lacobazzi $V$, Pasquali $M$, Singh $R$, et al. Response to therapy in carnitine/acylcarnitine translocase (CACT) deficiency due to a novel missense mutation. Am J Med Genet A 2004; 126A(2): 150-5. doi: 10.1002/ajmg.a.20573.

33. Korman SH, Pitt JJ, Boneh A, et al. A novel SLC25A20 splicing mutation in patients of different ethnic origin with neonatally lethal carnitine-acylcarnitine translocase (CACT) deficiency. Mol Genet Metab 2006; 89(4): 332-8. doi: 10.1016/j.ymgme.2006.06.009. Epub Aug 17.

34. Vatanavicharn N, Yamada K, Aoyama Y, et al. Carnitine-acylcarnitine translocase deficiency: Two neonatal cases with common splicing mutation and in vitro bezafibrate response. Brain \& development 2015; 37(7): 698-703.

35. Fukushima T, Kaneoka H, Yasuno $\mathrm{T}$, et al. Three novel mutations in the carnitineacylcarnitine translocase (CACT) gene in patients with CACT deficiency and in healthy individuals. J Hum Genet 2013; 58(12): 788-93. doi: 10.1038/jhg.2013.103. Epub Oct 3.

36. Al Aqeel Al, Rashid MS, Ruiter JP, Ijlst L, Wanders RJ. A novel molecular defect of the carnitine acylcarnitine translocase gene in a Saudi patient. Clin Genet 2003; 64(2): 163-5. doi: 10.1034/j.399-0004.2003.00117.x.

37. Bonnet $D$, Martin D, Pascale De $L$, et al. Arrhythmias and conduction defects as presenting symptoms of fatty acid oxidation disorders in children. Circulation 1999; 100(22): 2248-53. doi: 10.1161/01.cir.100.22.2248.

38. Ogier de Baulny H, Slama A, Touati G, Turnbull DM, Pourfarzam M, Brivet M. Neonatal hyperammonemia caused by a defect of carnitine-acylcarnitine translocase. J Pediatr 1995; 127(5): 723-8. doi: 10.1016/s0022-3476(95)70160-5.

39. Khabbush A, Orford M, Tsai YC, et al. Neuronal decanoic acid oxidation is markedly lower than that of octanoic acid: A mechanistic insight into the medium-chain triglyceride ketogenic diet. Epilepsia 2017; 58(8): 1423-9. doi: 10.111/epi.13833. Epub 2017 Jul 6.

40. Rogawski MA. A fatty acid in the MCT ketogenic diet for epilepsy treatment blocks AMPA receptors. Brain 2016; 139(Pt 2): 306-9. doi: 10.1093/brain/awv369.

41. Van Hove JL, Grunewald S, Jaeken J, et al. D,L-3-hydroxybutyrate treatment of multiple acyl-CoA dehydrogenase deficiency (MADD). Lancet (London, England) 2003; 361(9367): 1433-5.

42. Van Rijt WJ, Heiner-Fokkema MR, du Marchie Sarvaas GJ, et al. Favorable outcome after physiologic dose of sodium-D,L-3-hydroxybutyrate in severe MADD. Pediatrics 2014; 134(4): e1224-8.

43. Gautschi M, Weisstanner C, Slotboom J, Nava E, Zürcher T, Nuoffer JM. Highly efficient ketone body treatment in multiple acyl-CoA dehydrogenase deficiency-related leukodystrophy. Pediatr Res 2015; 77(1-1): 91-8. doi: 10.1038/pr.2014.154. Epub Oct 7. 44. Wang GL, Wang J, Douglas $G$, et al. Expanded molecular features of carnitine acylcarnitine translocase (CACT) deficiency by comprehensive molecular analysis. Mol Genet Metab 2011; 103(4): 349-57. doi: 10.1016/j.ymgme.2011.05.001. Epub May 7. 
45. Lee RS, Lam CW, Lai CK, et al. Carnitine-acylcarnitine translocase deficiency in three neonates presenting with rapid deterioration and cardiac arrest. Hong Kong Med J 2007; 13(1): 66-8. 
MCT procal, skimmed milk, and carbohydrate polymer, with walnut oil supplementation. He received continuous overnight gastrostomy feeds from 17 months of age. His diet provided 30 to $40 \%$ of total calories from fat with less than $10 \%$ from long chain fat. Energy intake was $83-116 \%$ of expected energy requirement (EER) but poor growth and worsening hyperammonemia was noted with energy intake less than $85 \%$ EER. Hyperammonemia improved but transaminases and hepatomegaly appeared to worsen with increased dietary carbohydrate. AT 2 year and 10 months of age he started a transition to C7 oil and Tolerex (Nestlé, Vevey, Switzerland) low fat elemental formula. Despite no previous history of elevated Creatine Kinase (CK) levels, he developed increased Creatine Kinase up to $2841 \mathrm{U} / \mathrm{L}$ $(<235)$ and worsening of transaminases. These improved with Portagen, MCT procal and skim milk feeds. Dilated cardiomyopathy was documented at 3 years and 3 months of age with Left Ventricular Ejection Fraction of $27 \%$ (severe dysfunction <30\%). At 3 years and 6 months of age, he was admitted with intercurrent illness and died of cardiac failure.

\section{Patient 2}

A female infant of Indian ethnicity was born at term, after a pregnancy complicated by a mild increase in maternal GGT. Apgars were $9^{1}$ and $10^{5}$ and growth parameters were between 2$9^{\text {th }}$ percentile. She presented at 12 hours of age with poor feeding, hypothermia and hypoglycaemia, proceeding to a bradycardic arrest with blood glucose level of $0.5 \mathrm{mmol} / \mathrm{L}$ $(2.6-5.0)$. Return of spontaneous circulation was achieved after 10 minutes of cardiopulmonary resuscitation however she developed encephalopathy and seizures. She received total body cooling for a total of 69 hours for presumed hypoxic encephalopathy and developed elevated liver transaminases with deranged coagulation, renal impairment and hyponatremia. Worsening metabolic acidosis on day 5 culminated in bradycardiac arrest and resuscitation was unsuccessful. Biochemical test results were available post mortem. Plasma free carnitine was reduced $3.1 \mathrm{umol} / \mathrm{L}$ (4-33) with a raised acyl/free-carnitine ratio. Plasma acylcarnitine profile was suggestive of CPT II/CACT with an elevated C16 of $12.61 \mathrm{umol} / \mathrm{L}$ $(<0.7)$. Molecular analysis of $S L C 25 A 20$ revealed compound heterozygous variants $\mathrm{C} .82 \mathrm{G}>\mathrm{T} /$ c. $706 \mathrm{C}>\mathrm{T}$.

\section{Patient 3 (previously reported by Hammond et al as abstract in 1998)}

A female infant was born to consanguineous Vietnamese parents at 36/40 after an uncomplicated pregnancy. Birth weight was $2775 \mathrm{~g}$. At 28 hours of age she developed hypoglycaemia and hypothermia, which persisted despite external warming and regular formula feeds. Hypoglycaemia and hypothermia resolved on intravenous $10 \%$ dextrose but recurred on attempted reintroduction of feeds. Initial metabolic screen showed mildly elevated ammonia and lactate with a respiratory alkalosis, severely reduced serum carnitine, raised acylcarnitine/free carnitine ratio and normal urine organic acids. A long chain fat disorder was suspected, regular feeds were ceased, and L-carnitine and IV 10\% dextrose started at $7-9 \mathrm{mg} / \mathrm{kg} / \mathrm{min}$. IV dextrose up to $13 \mathrm{mg} / \mathrm{kg} / \mathrm{min}$ was required to maintain blood sugar levels 4-6mmol/L. On return to full Pregestamil (53\% MCT) feeds off dextrose, blood sugar levels were maintained but ammonia and lactate remained elevated. A repeat metabolic screen showed a compensated metabolic acidosis, dicarboxylic aciduria, and renal Fanconi's syndrome, which was treated with sodium bicarbonate $8.4 \%$ oral solution. Free carnitine remained low at $7 \mathrm{umol} / \mathrm{L}$, despite supplementation with L-carnitine $50 \mathrm{mg} / \mathrm{kg} / \mathrm{day}$. 
Figure 1.

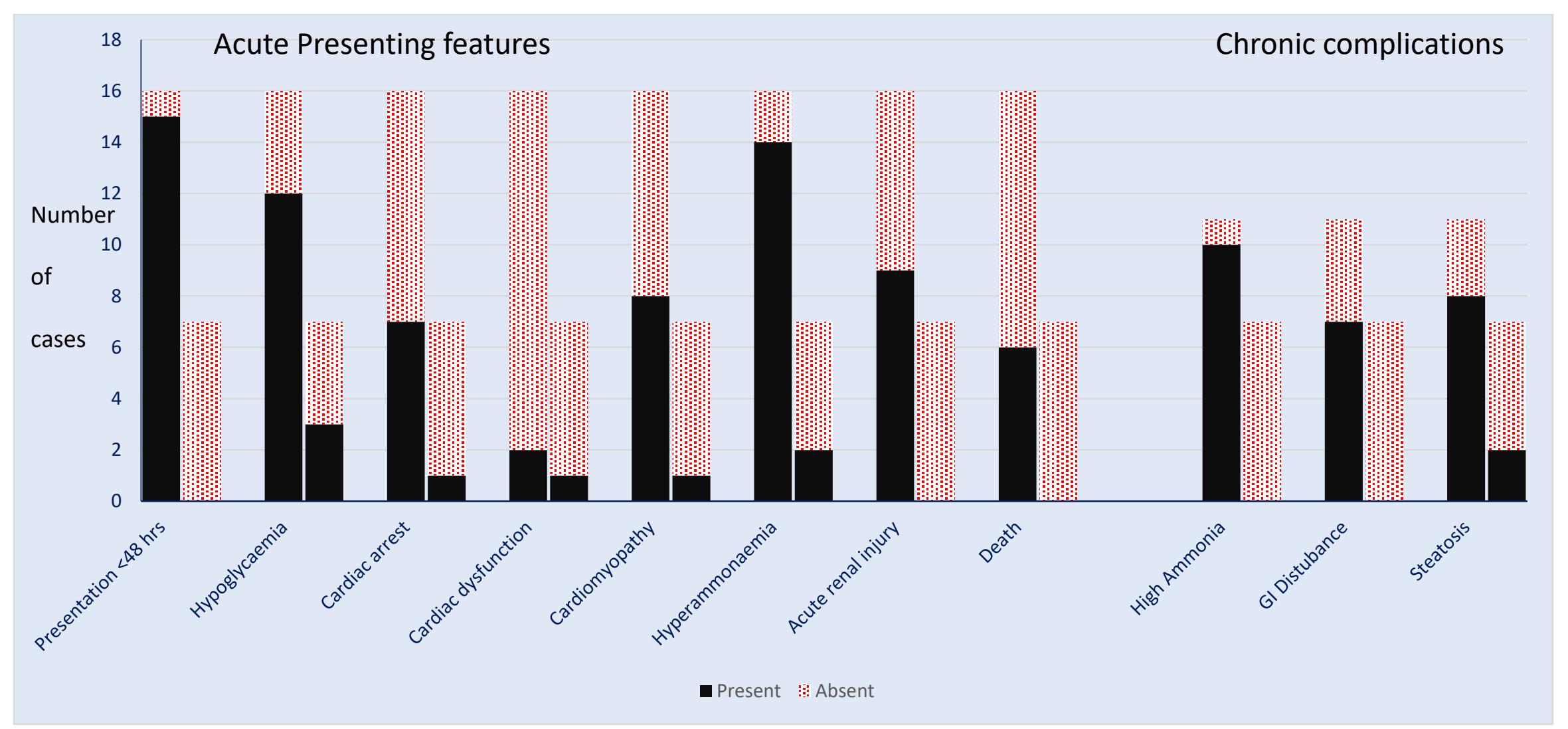




\begin{tabular}{|c|c|c|c|c|c|c|c|c|c|c|c|c|c|c|c|c|}
\hline Patient ID & 1 & 2 & 3 & 4 & 5 & 6 & 7 & 8 & 9 & 10 & 11 & 12 & 13 & 14 & 15 & 16 \\
\hline Age at onset & 24 hours & 12 hours & 28 hours & 24 hours & 10 hours & Day 2 & 24 hrs & 24 hours & 15 hours & Day 2 & $\begin{array}{l}\begin{array}{l}\text { Treated from } \\
\text { birth }\end{array} \\
\text { (a) }\end{array}$ & 32 hours & 36 hours & 14.5 hours & Day 8 & 12 hours \\
\hline Ethnicity & Chinese & Indian & Vietnamese & $\begin{array}{c}\text { Caucasian } \\
\text { (NZ) }\end{array}$ & Caucasian & & Iranian & Chinese & $\begin{array}{l}\text { Guyana/ } \\
\text { Surinam }\end{array}$ & $\begin{array}{c}\text { Caucasian } \\
\text { (Aus) }\end{array}$ & Iranian & Irish & NZ Maori & Chinese & Chinese & Vietnamese \\
\hline $\begin{array}{c}\text { Lowest Glu } \\
(\mathrm{mmol} / \mathrm{L})\end{array}$ & 1.1 & 0.5 & LOW & LOW & 1.4 & 1.5 & $<2.0$ & $<0.5$ & No & 1.9 & No & LOW & $<0.6$ & $<1.1$ & 2.3 & 0.6 \\
\hline $\begin{array}{c}\text { Cardiac } \\
\text { arrest }\end{array}$ & Yes & Yes & No & $\begin{array}{c}\text { not } \\
\text { documented }\end{array}$ & Yes & No & Yes & No & No & No & No & Yes & No & Yes & No & Yes \\
\hline $\begin{array}{c}\text { Presenting } \\
\text { cardiac } \\
\text { findings }\end{array}$ & $\left|\begin{array}{l}\text { RBBB, first- } \\
\text { degree heart } \\
\text { block. LVH }\end{array}\right|$ & $\begin{array}{c}\text { Bradycardic } \\
\text { arrest (ROSC } \\
\text { after 10 minutes) }\end{array}$ & $\begin{array}{c}\text { Normal echo } \\
\text { ECG }\end{array}$ & AV block & $\begin{array}{l}\text { VT and cardiac } \\
\text { arrest requiring } \\
45 \text { mins CPR. }\end{array}$ & $\begin{array}{c}\text { Severe } \\
\text { hypertrophic } \\
\text { cardiomyopathy }\end{array}$ & \begin{tabular}{|c|} 
SVT, cardiac \\
arrest, mild LVH \\
visually (normal \\
measurements)
\end{tabular} & \begin{tabular}{|c|} 
Broad complex \\
tachyarrhythmia \\
atrial flutter; \\
biventricular \\
hypertrophy, \\
troponin rise \\
\end{tabular} & Yes & $\begin{array}{c}\text { Severe } \\
\text { cardiac } \\
\text { dysfunction } \\
(\mathrm{FS} \mathrm{16 \% )}\end{array}$ & \begin{tabular}{|c|} 
SVT and ?VT. \\
$\quad$ Normal \\
echocardiogram
\end{tabular} & $\begin{array}{c}\text { Out of hospital } \\
\text { arrest. AV broad } \\
\text { complex - (PEA) }\end{array}$ & \begin{tabular}{|l|} 
Concentric LVH. \\
Dysfunction with \\
echogenic \\
myocardium
\end{tabular} & $\begin{array}{c}\text { Bradycardia, } \\
\text { cardiomyopathy } \\
\text { with thickened } \\
\text { LV, RV and } \\
\text { septum. }\end{array}$ & $\begin{array}{c}\text { Hypertrophic } \\
\text { cardiomyopathy, } \\
\text { episodic } \\
\text { bradycardia }\end{array}$ & $\begin{array}{l}\text { VT arrest during } \\
\text { intubation. } \\
\text { Responded to } \\
\text { defibrillation }\end{array}$ \\
\hline $\begin{array}{l}\text { Highest } \\
\text { Ammonia }\end{array}$ & 319 & NP & $\begin{array}{c}\text { Raised, level } \\
\text { not } \\
\text { documented }\end{array}$ & \begin{tabular}{c|c|} 
Not \\
documented
\end{tabular} & 590 & 195 & 50 & 190 & 1142 & 800 & 121 & 250 & 320 & 316 & 415 & 388 \\
\hline $\begin{array}{l}\text { Other clinical } \\
\text { features }\end{array}$ & \begin{tabular}{|c|} 
Acidosis. \\
Seizures, \\
Acute renal \\
injury
\end{tabular} & \begin{tabular}{|c|} 
Acidosis. \\
Encephalopathy, \\
seizures, \\
hypocalcaemia, \\
renal impairment \\
\end{tabular} & \begin{tabular}{|c|} 
Alkalosis and \\
acidosis (renal \\
tubular \\
dysfunction) \\
hypothermia \\
\end{tabular} & $\begin{array}{c}\text { Apnoea, } \\
\text { hypothermia } \\
\text { acidosis. }\end{array}$ & $\begin{array}{l}\text { Anuria, acidosis. } \\
\text { Cerebral oedema }\end{array}$ & $\begin{array}{l}\text { Elective NICU } \\
\text { admission. }\end{array}$ & \begin{tabular}{c|} 
Acidosis, \\
hypothermia, \\
seizures \\
elevated \\
transaminases, \\
\end{tabular} & $\begin{array}{c}\text { Seizures, elevated } \\
\text { transaminases }\end{array}$ & $\begin{array}{l}\text { Hypotonia, } \\
\text { encephalopathy }\end{array}$ & $\begin{array}{c}\text { Acidosis, } \\
\text { Hypothermia, } \\
\text { seizures, renal } \\
\text { impairment }\end{array}$ & $\begin{array}{l}\text { Elective } \\
\text { treatment - } \\
\text { sibling died }\end{array}$ & $\begin{array}{c}\text { Acidosis, acute } \\
\text { renal injury, mild } \\
\text { coagulopathy }\end{array}$ & & $\begin{array}{c}\text { Seizures } \\
\text { Acute renal } \\
\text { failure and } \\
\text { rhabdomyolysis }\end{array}$ & \begin{tabular}{|c|} 
Elevated \\
transaminases, \\
Hypothermia, \\
respiratory \\
distress \\
\end{tabular} & $\begin{array}{l}\text { Hypoglycaemic } \\
\text { seizures }\end{array}$ \\
\hline $\begin{array}{c}\mathbf{C K}(\mathbf{U} / \mathbf{L}) \\
(<300) \\
\end{array}$ & 625 & & Raised & 14,000 & & 430 & $>25,000$ & 1560 & normal & 762 & 190 & 23200 & 7440 & 480 & 1171 & 3836 \\
\hline $\begin{array}{c}\begin{array}{c}\text { Peak Lactate } \\
\mathrm{mmol} / / \mathrm{I}\end{array} \\
\end{array}$ & 4.5 & 8.0 & $\mathrm{NR}$ & Raised & 5.1 & 5.6 & 6.0 & 6.9 & & 4.0 & $\mathrm{NP}$ & 5 & & 4.7 & 1.4 & 4.5 \\
\hline $\begin{array}{c}\begin{array}{c}\text { Free carn } \\
(\text { MLN) }\end{array} \\
\end{array}$ & 0.18 & 0.25 & 0.083 & 7 (day 10) & 1.2 & 0.4 & 0.04 & 1 & & 1 & 0.4 & in range & 1 & 1.1 & 0.5 & 1 \\
\hline C16 (MUN) & 29 & 1 & 1.1 & NA & 10.1 & C16 increased & 1.1 & 1.7 & 12.6 (day 9) & 1.2 & 3.35 & 7.8 & 1.7 & 14 & 18 & 3.3 \\
\hline $\begin{array}{c}\text { Urine organic } \\
\text { acids }\end{array}$ & $\begin{array}{c}\text { Dicarboxylic } \\
\text { aciduria. No } \\
\text { ketones }\end{array}$ & & $\begin{array}{c}\text { Dicarboxylic } \\
\text { aciduria, } \\
\text { lactate, } \\
\text { tyrosine } \\
\text { metabolites }\end{array}$ & \begin{tabular}{|} 
Lactate, C6, \\
C8,C8:1, \\
C10:1 \\
dicarboxylic \\
aciduria
\end{tabular} & No urine passed & $\begin{array}{c}\text { Increased lactate, } \\
\text { moderate } \\
\text { dicarboxylic } \\
\text { aciduria }\end{array}$ & $\begin{array}{c}\text { Dicarboxylic } \\
\text { aciduria with } \\
\text { modest lactate } \\
\text { elevation }\end{array}$ & \begin{tabular}{|c|} 
Lactate slight \\
increase and \\
dicarboxylic acids \\
slightly increased
\end{tabular} & $\underset{\text { Dicarboxylic }}{\text { aciduria }}$ & $\begin{array}{c}\text { Dicarboxylic } \\
\text { aciduria in } \\
\text { absence of } \\
\text { ketones. }\end{array}$ & $\begin{array}{c}\text { Mild lactic } \\
\text { aciduria. Trace } \\
\text { hexanoylglycine } \\
\text { suberylglycine }\end{array}$ & $\begin{array}{c}\text { Mild elevation of } \\
3- \\
\text { hydroxycarboxyl } \\
\text { ic acids, with } \\
\text { normal ketones }\end{array}$ & $\begin{array}{c}\text { Significant } \\
\text { dicarboxylic } \\
\text { aciduria C6-C12 }\end{array}$ & \begin{tabular}{|c} 
Dicarboxylic \\
acids, tyrosine \\
metabolites
\end{tabular} & $\begin{array}{l}\text { Dicarboxylic } \\
\text { acids }\end{array}$ & $\begin{array}{c}\text { Mild to moderate } \\
\text { dicarboxylic } \\
\text { aciduria } \\
(\mathrm{C} 6>\mathrm{C} 8>\mathrm{C} 10) \\
\text { No other } \\
\text { significant } \\
\text { changes } \\
\text { detected. }\end{array}$ \\
\hline $\begin{array}{l}\text { Enzyme } \\
\text { activity }\end{array}$ & $\mathrm{NP}$ & & $\begin{array}{c}0 \% \text { CACT } \\
\text { activity }\end{array}$ & \begin{tabular}{|c|} 
CACT \\
enzyme \\
activity $4 \%$ of \\
controls
\end{tabular} & $\mathrm{NP}$ & $\begin{array}{c}1 \% \text { of controls: } \\
0.0175(1.24) \\
\mathrm{nmml} / \mathrm{min} / \mathrm{mg} \\
\text { prot }\end{array}$ & & $\mathrm{NP}$ & $\mathrm{NP}$ & \begin{tabular}{|c|} 
CACT / CPT \\
II fib ACP \\
pattern \\
(normal \\
CPTII) \\
\end{tabular} & $\mathrm{NP}$ & $\mathrm{NP}$ & & $\mathrm{NP}$ & $\mathrm{NP}$ & $\mathrm{NP}$ \\
\hline $\begin{array}{c}\text { SLC25A20 } \\
\text { genotype }\end{array}$ & $\left|\begin{array}{l}\text { Homozygous } \\
\text { c. 199-10T }>\mathrm{G}\end{array}\right|$ & $\begin{array}{l}\text { c. } 82 \mathrm{G}>\mathrm{T} \\
\text { c. } 706 \mathrm{C}>\mathrm{T}\end{array}$ & $\begin{array}{l}\text { Homozygous } \\
\mathrm{c} .199-10 \mathrm{~T}>\mathrm{G}\end{array} \mid$ & & $\begin{array}{c}\text { c. } 646 \mathrm{G}>\mathrm{T} \\
\text { Homozygous }\end{array}$ & $\mathrm{NP}$ & $\begin{array}{l}\text { Homozygous } \\
\text { c. } 67 \mathrm{~T}>\mathrm{C}\end{array}$ & $\begin{array}{c}\text { c. } 109 \mathrm{C}>\mathrm{T} \\
\text { c. } 199-10 \mathrm{~T}>\mathrm{G}\end{array}$ & $\begin{array}{c}\text { Homozygous } \\
\text { c.110G }>\mathrm{C}\end{array}$ & $\mid \begin{array}{c}\text { c. } 50 \mathrm{G}>\mathrm{C} \\
\mathrm{c} .326+1 \mathrm{delG}\end{array}$ & $\begin{array}{l}\text { Homozygous } \\
\text { c. } 417+1 \mathrm{G}>\mathrm{A}\end{array}$ & $\begin{array}{l}\text { c.326+1delG } \\
\text { (Splice donor) ; } \\
\text { c.691G }>\mathrm{C}\end{array}$ & $\begin{array}{l}\text { Homozygous } \\
\text { c. } 804 \text { delG }\end{array}$ & $\begin{array}{l}\text { Homozygous } \\
\text { c. 199-10T>G }\end{array}$ & $\begin{array}{l}\text { Homozygous } \\
\text { c.199-10T>G }\end{array}$ & $\begin{array}{l}\text { Homozygous } \\
\text { c. } 199-10 \mathrm{~T}>\mathrm{G}\end{array}$ \\
\hline$\left|\begin{array}{c}\text { Current Age } \\
\text { age \& mode of } \\
\text { of death }\end{array}\right|$ & $\begin{array}{c}\text { 3yrs } \\
\text { ?cardiac } \\
\text { arrest }\end{array}$ & $\begin{array}{c}7 \text { days - cardiac } \\
\text { arrest }\end{array}$ & $\begin{array}{c}6 \text { months - } \\
\text { broad } \\
\text { complex VT }\end{array}$ & \begin{tabular}{|c|}
6 months - \\
out of \\
hospital \\
sudden death
\end{tabular} & \begin{tabular}{|c|} 
Care \\
withdrawn on \\
day 3 of life.
\end{tabular} & $\begin{array}{c}2 \text { yrs } 10 \text { months } \\
\text { - post-viral } \\
\text { multi-organ } \\
\text { failure }\end{array}$ & 11 years & 9 years & 3 years & 10 years & 19 months & 16 months & 12 months & 4 years & 14 months & 5 months \\
\hline
\end{tabular}


Table 1 - Presenting features of patients with early severe classical-onset CACTD. All except patient 15 presented < 48 hours of life. Patients $7-16$ still survive. VT - ventricular tachycardia. SVT - supraventricular tachycardia. PEA - Pulseless electrical activity. RBBB - right bundle branch block. LVH - left ventricular hypertrophy. Free carn (Free carnitine - MLN - multiple of lower normal reference range); C16 (MUN - multiples of upper normal reference range). Glu - Blood Glucose level (normal range typically $2.6-5.0 \mathrm{mmols} / \mathrm{L}$ ) - LOW represents value below detection limit. Lactate normal range typically $<2.0 \mathrm{mmols} / \mathrm{L}$. Ammonia - normal range typically $<80$ umol/L. NZ - New Zealand; Aus - Australia

\begin{tabular}{|c|c|c|c|c|c|c|c|c|c|c|c|c|}
\hline Patient ID & 1 & 6 & 7 & 8 & 9 & 10 & 11 & 12 & 13 & 14 & 15 & 16 \\
\hline $\begin{array}{c}\text { Energy Intake } \\
\text { kcal/kg/day }\end{array}$ & 68 & 105 & 53 & & 90 & 90 & 87 & 66 & 98 & & & 98 \\
\hline $\begin{array}{l}\text { Total Energy } \\
\text { Intake (\%EER) }\end{array}$ & 82 & & 112 & & & 104 & 92 & & 111 & 130 & 115 & 102 \\
\hline $\begin{array}{l}\text { Total fat (\% of } \\
\text { total energy) }\end{array}$ & 34 & 7 & 25 & 29 & 31 & 19 & 20 & 25 & 23 & 30 & $21-24$ & 22 \\
\hline $\begin{array}{c}\text { LCT (\% of total } \\
\text { energy) }\end{array}$ & 9 & 5 & 4 & 5 & 9 & 8 & 3 & 4 & 4 & 4 & $<10$ & 3.5 \\
\hline $\begin{array}{c}\begin{array}{c}\text { MCT (\% of total } \\
\text { energy) }\end{array} \\
\end{array}$ & 25 & 2 & 21 & 24 & C7 24 & 11 & C8 (17) & 21 & 19 & 26 & & 18.5 \\
\hline Protein $\mathbf{g} / \mathbf{k g}$ & 2.5 & 3.0 & 1.4 & 1.2 & 2.0 & 3.0 & 1.7 & 2.4 & 2.8 & & & 3.1 \\
\hline $\begin{array}{l}\text { Protein (\% of } \\
\text { total energy) }\end{array}$ & 15 & 14 & 11 & 10 & 9 & 16 & 8 & 11 & 12 & 10 & 11 & 9.8 \\
\hline $\begin{array}{c}\% \text { calories from } \\
\mathrm{CHO}\end{array}$ & 51 & 78 & 64 & 60 & 60 & 65 & 72 & 64 & 64 & 60 & $65-67$ & 69.3 \\
\hline $\begin{array}{c}\text { Maximum fasting } \\
\text { interval }\end{array}$ & & $3 \mathrm{hrs}$ & $2.5 \mathrm{hrs}$ & \begin{tabular}{|l} 
Reached 11 \\
hrs; reduced \\
back to 4 hrs
\end{tabular} & 6hrs CNPF & $4 \mathrm{hrs}$ & $3 \mathrm{hrs}$ & $4 \mathrm{hrs}$ & $\begin{array}{l}4 \mathrm{hrs} \text { (reduced } \\
\text { from } 8 \mathrm{hrs} \text { ) }\end{array}$ & & & $4 \mathrm{hrs}$ \\
\hline Supplements & Walnut oil, C7 & Walnut oil & $\begin{array}{c}\text { Flax seed oil, } \\
\text { multivitamins, } \\
\text { essential } \\
\text { amino acids, } \\
\text { ketones }\end{array}$ & $\begin{array}{c}\text { Beneprotein, } \\
\text { Ketones }\end{array}$ & Ketones, C7 & Ketones & PUFA & Ketones & $\begin{array}{l}\text { Beneprotein } \\
\text { Ketones }\end{array}$ & Walnut oil & & Ketones \\
\hline $\begin{array}{l}\text { L-carnitine } \\
\text { (mg/kg/day) }\end{array}$ & up to 125 & Yes & Yes & $\begin{array}{c}100 \\
\text { (re-started } 10 \\
\text { yrs ) }\end{array}$ & 100 & 100 & 22 & 100 & $\begin{array}{c}100 \\
\text { (poor } \\
\text { compliance) }\end{array}$ & $130-150$ & 130 & 50 \\
\hline
\end{tabular}


Table 2 - Dietary Treatment of severe early onset CACT deficiency in patients that survived neonatal period. EER - estimated energy requirement. MCT - medium chain triglyceride. LCT - long chain triglyceride. CHO - carbohydrate. PUFA -long chain poly-unsaturated fatty acids. C7 - Triheptanoin.

CNPF - continuous nocturnal pump feeds.

\begin{tabular}{|c|c|c|c|c|c|c|c|}
\hline Patient identifier & 17 & 18 & 19 & 20 & 21 & 22 & 23 \\
\hline Age at onset & NBS +ve (day 9) & 2 months & Prospective $\mathrm{Rx}$ & Day 9 & Prospective Rx & 1 month & 4 months \\
\hline Hypoglycemia & No & Yes & No & Yes & No & No & Yes \\
\hline Presenting cardiac findings & Normal echo, ECG & $\begin{array}{l}\text { Asystolic arrest requiring } \\
\text { CPR for } 2 \text { minutes LVH, } \\
\text { Impaired contractility. }\end{array}$ & Small ASD only & $\begin{array}{l}\text { Mild left branch } \\
\text { pulmonary stenosis }\end{array}$ & Normal & Normal & $\begin{array}{l}\text { Mild left ventricular } \\
\text { hypertrabeculation }\end{array}$ \\
\hline Other clinical features & & Seizures & Nil & Nil & Nil & Nil & $\begin{array}{l}\text { Unresponsive after } \\
\text { missing night feed - } \\
\text { glucose }<0.6 \mathrm{mmol} / \mathrm{L}\end{array}$ \\
\hline Free carnitine (MLN) & 0.47 & 0.67 & NP & 1.2 & 0.84 & 0.04 & 0.8 \\
\hline C16-acylcarnitine (MUL) & 13 & C16 increased & & C16 increased & & & 1.23 \\
\hline Urine organic acids & $\begin{array}{c}\text { Normal at } 9 \text { days of } \\
\text { age. }\end{array}$ & $\begin{array}{l}\text { 4-hydroxyphenyllactate \& 4- } \\
\text { hydroxyphenylpyruvate } \\
\text { (Liver dysfunction) }\end{array}$ & $\begin{array}{c}\text { Grossly increased } \\
\text { adipate, suberate \& } \\
\text { sebacate - but on } \\
\text { MCT } \\
\text { supplementation } \\
\end{array}$ & $\begin{array}{c}\text { Benzoate \& succinate } \\
\text { increased (specimen } \\
\text { deterioration) }\end{array}$ & NA & $\begin{array}{c}\text { DCA present, } \\
\text { minimal } 3 \text { hydroxy- } \\
\text { n-buyrate }\end{array}$ & Normal \\
\hline Enzyme activity & Normal VLCAD activity & CACT enzyme activity $4 \%$ : & NP & NP & NP & $\begin{array}{c}\text { Normal CPT1 and } \\
\text { CPT2 }\end{array}$ & $N P$ \\
\hline Beta oxidation & FAO flux $12 \%$ & $\begin{array}{c}\text { Defective oxidation of oleate, } \\
\text { Myristate and Myr/Oleate } \\
\text { ratio }\end{array}$ & $\begin{array}{l}\text { Defective oxidation of } \\
\text { myristate and oleate }\end{array}$ & NP & NP & NP & NP \\
\hline Abdominal ultrasound & Normal & Normal & $\begin{array}{l}\text { Liver echogenicity. } \\
\text { No gallstones. }\end{array}$ & Normal & Normal & Normal & $\begin{array}{l}\text { Mild increase in } \\
\text { echogenicity }\end{array}$ \\
\hline
\end{tabular}




\begin{tabular}{|c|c|c|c|c|c|c|c|}
\hline Neuroimaging & MRI/MRS normal. & NA & NA & NA & NA & NP & NP \\
\hline Other & $\begin{array}{c}\text { Normal growth and } \\
\text { development. Diabetes } \\
\text { insipidus. }\end{array}$ & $\begin{array}{c}\text { Spastic quadriplegia, } \\
\text { microcephaly, severe } \\
\text { learning difficulties, oral diet }\end{array}$ & $\begin{array}{c}\text { Normal development. } \\
\text { Overweight. }\end{array}$ & $\begin{array}{c}\text { Normal growth \& } \\
\text { development but } \\
\text { learning support at } \\
\text { school }\end{array}$ & $\begin{array}{l}\text { Normal growth \& } \\
\text { development }\end{array}$ & $\begin{array}{c}\text { Normal. Not } \\
\text { compliant with diet }\end{array}$ & \\
\hline Total Energy Intake (\%EER) & 66 & 105 & 117 & 98 & 98 & & \\
\hline Total fat (\% Energy from fat) & 30 & 7 & 22 & 20 & 29 & & \\
\hline LCT (\% Energy from LCT) & 13 & 5 & 2 & 4 & 6 & & \\
\hline MCT g (\% calories from MCT & 17 & 2 & 20 & 18 & 23 & & \\
\hline Protein $\mathrm{g} / \mathrm{kg} /$ day & 1.1 & 2 & 3 & 2.3 & 2.3 & & \\
\hline Protein (\% Energy from protein) & 16 & 13 & 13 & 13 & 13 & & \\
\hline$\%$ calories from $\mathrm{CHO}$ & $54 \%$ & $80 \%$ & $65 \%$ & $65 \%$ & $58 \%$ & & \\
\hline Maximum fasting interval & 12 & 6 hours (on profile) & 13 hours (on profile) & 5 hours (on profile) & 4 hours (on profile) & & \\
\hline Supplements & Walnut oil, flax oil & Walnut oil & Non compliant (EFA) & Non compliant (EFA) & NA & & \\
\hline L-carnitine & Yes & Yes & Yes & Yes & Yes & No & Yes \\
\hline Current age (years) & 10 & 20 & 16 & 10 & 5 & 25 & 8 \\
\hline
\end{tabular}

Table 3 Features of later onset CACT deficiency - all of Pakistani heritage. Genetic studies performed in all cases except case 22 and were homozygous c.82G $>$ T (p.Gly28Cys). Diet data were unreliable for case 22 and 23. NP - not performed. NA - not applicable. MLN - multiples of lower limit of normal. MUL - multiples of upper limit of normal. EER - estimated energy requirement. MCT - medium chain triglyceride. LCT - long chain triglyceride. CHO carbohydrate. EFA - essential fatty acid supplement - Arachidonic Acid and Docosahexaenoic Acid. 